\title{
Effect of Plant Geometry on the Economics of Sweet Corn (Zea mays) Varieties in Prayagraj Climatic Condition
}

\author{
Nawazish Rezaie", Rajesh Singh and Ekta Singh \\ Department of Agronomy, Sam Higginbottom University of Agriculture, Technology and Sciences, Prayagraj, Uttar Pradesh, India \\ *Corresponding author: r.nawazish12@gmail.com
}

Received: $17-03-2021$

Revised: $14-05-2021$

Accepted: 12-06-2021

\begin{abstract}
An experiment was carried out during zaid season of 2020 at Crop Research Farm, NAI, SHUATS, Prayagraj (India) to the effect of plant geometry on the economics of sweet corn varieties in Prayagraj climatic condition. The experiment consisted of 9 treatments which includes three varieties of sweet corn (Sugar-75, Sweet Glory and Hybrid Indam-Suruchi) used with three different spacing $(45 \mathrm{~cm} \times 15$ $\mathrm{cm}, 50 \mathrm{~cm} \times 15 \mathrm{~cm}$ and $55 \mathrm{~cm} \times 15 \mathrm{~cm}$ ). The result revealed that, treatment $55 \mathrm{~cm} \times 15 \mathrm{~cm}+$ Sugar -75 recorded maximum plant height $(112.63 \mathrm{~cm})$, no. of cobs/plant $(1.17)$, cob yield $(10.06 \mathrm{t} / \mathrm{ha})$ and B:C ratio (2.07), whereas maximum stover yield was recorded with treatment $50 \times 15+$ Sugar $-75(2.85 \mathrm{t} / \mathrm{ha})$ and net return (INR $\left.90.56 \times 10^{3} / \mathrm{ha}\right)$.
\end{abstract}

Keywords: Sweet corn, Varieties, Yield, Economics, spacing and economics

Sweet corn (Zea mays var. saccharate) also known as sugar corn pole corn is a variety of maize with high sugar content. It is one of the most widely grown cereals in the world and his great significance as human food, animal food and raw materials for large number of industrial products. It is becoming more popular in India and other Asian countries because it vary from other corns (Field maize, popcorn and ornamental) with higher level of sugar content in early dough stage.

It is consumed in the immature stage of the crop. The kernels of sweet corn taste considerable sweeter than normal corn, especially at $25-30 \%$ maturity (Naik, 2019). In India, maize is cultivated in an area of 9.63 million ha with grain production of 25.89 million tonnes and productivity of $2689 \mathrm{~kg} / \mathrm{ha}$ (www.indiastat.com) (2016-2017). From this, about $50-55 \%$ of the total maize consumed for the food, 30 $35 \%$ goes for poultry, piggery and fish meal industry and $10-12 \%$ to wet milling industry (Thakur, 2015). Since there is a bound scope to enlarge the area under maize cultivation because of competition from other cereals and commercial crops, the only alternative is through enhancement of productivity by various management factors. In order to achieve higher cob yields, maintenance of plant density is the most important factor. A spatial arrangement of plant governs the shape and size of the leaf area per plant, which in turn influences efficient interception of radiant energy, proliferation, growth of roots and their activity. Maximum yield can be expected only when plant population allows individual plant to achieve their maximum inherent potential. Thus, there is need to work out an optimum population density by adjusting inter and intra row spacing in relation to other agronomic factors (Naik, 2019).

\section{MATERIALS AND METHODS}

This experiment was carried out during zaid season

How to cite this article: Rezaie, N., Singh, R. and Singh, E. (2021).
Effect of Plant Geometry on the Economics of Sweet Corn (Zea mays)
Varieties in Prayagraj Climatic Condition. International Journal of
Bioresource Science, 08(01): 35-37.
Source of Support: None; Conflict of Interest: None 
of 2020 at Crop Research Farm, Department of Agronomy, Naini Agricultural Institute, SHUATS, Prayagraj (India). The soil was sandy loam in texture, low in organic carbon $(0.47 \%)$. Available Phosphorus $11 \mathrm{~kg} / \mathrm{ha}$ and potassium $233 \mathrm{~kg} / \mathrm{ha}$ (Bouyoucos, 1927; Olsen et al. 1954 and Toth and Prince, 1949). The experiment was laid out in Randomised Block Design (RBD) with 9 treatments and replicated thrice. Three varieties of sweet corn (Sugar-75, Sweet Glory and Hybrid Indam-Suruchi) used with three different spacing $(45 \mathrm{~cm} \times 15 \mathrm{~cm}$, $50 \mathrm{~cm} \times 15 \mathrm{~cm}$ and $55 \mathrm{~cm} \times 15 \mathrm{~cm}$ ).

Here we justified the economic importance of sweet corn on the basis of plant geometry. Plant height (cm), no. of cobs per plant (no.), cob yield (t/ha), straw yield (t/ha) recorded at harvest. Also observed the net returns (INR) and $\mathrm{B}: \mathrm{C}$ ratio.

\section{Through the formula}

Net return $=$ Gross return - Cost of cultivation

B: $\mathbf{C}$ ratio $=($ Net return $/$ Cost of cultivation $) \times 100$

\section{RESULTS AND DISCUSSION}

\section{Plant height}

Maximum plant height was recorded on $55 \mathrm{~cm}$ $\times 15 \mathrm{~cm}+$ Sugar -75 (112.63 cm), which was significantly at par with $50 \mathrm{~cm} \times 15 \mathrm{~cm}+$ Sugar $-75(111.87 \mathrm{~cm})$. The plant height at harvest was influenced significantly due to different spacing.
Highest plant height in treatment $55 \times 15+$ Sugar -75 was due to wider spacing which helps in efficient utilization of natural resources like solar radiation, moisture and nutrients. This help in high photosynthesis activity leading to better growth. Similar findings were also reported by Thakur et al. (2000). Reduction in plant growth with increased inter row spacing and decreased intra row spacing seems to be the resultant of mutual shading due to overcrowding of plants, which might have reduced the availability of light within the crop canopy and inhibited elongation of lower internodes (Sahoo and Mahapatra, 2007).

\section{No. of cobs/ plant}

Maximum no. of cobs per plant was recorded on $55 \mathrm{~cm} \times 15 \mathrm{~cm}+$ Sugar -75 (1.17), which was significantly superior over all the treatments. Higher no. of cobs due to more nutrients and the basis of variety. The results are in conformity with that of; Dangariya et al. (2011); Sahoo and Mahapatra (2004); and Kar et al. (2006).

\section{Cob yield}

Significant and highest cob yield (10.32 t/ha) was observed under $50 \times 15+$ Sugar -75 , however, 55 $\mathrm{cm} \times 15 \mathrm{~cm}+$ Sugar $-75(10.06 \mathrm{t} / \mathrm{ha})$ were found to be statistically on par with $50 \mathrm{~cm} \times 15 \mathrm{~cm}+$ Sugar -75. The plant spacing had significant influence of cob yield. The increase in the yield recorded in this

Table 1: Effect of plant geometry on sweet corn varieties

\begin{tabular}{|c|c|c|c|c|c|c|}
\hline Treatment & $\begin{array}{l}\text { Plant height } \\
(\mathrm{cm})\end{array}$ & $\begin{array}{l}\text { No. of cobs/ } \\
\text { plant (no.) }\end{array}$ & $\begin{array}{l}\text { Cob Yield } \\
\text { (t/ha) }\end{array}$ & $\begin{array}{l}\text { Straw yield } \\
\text { (t/ha) }\end{array}$ & $\begin{array}{l}\text { Net returns }\left(\times 10^{3}\right. \\
\text { INR/ha })\end{array}$ & $\begin{array}{l}\mathrm{B}: \mathrm{C} \\
\text { ratio }\end{array}$ \\
\hline $45 \mathrm{~cm} \times 15 \mathrm{~cm}+$ Sugar -75 & 108.67 & 1.03 & 8.8 & 12.33 & 68.67 & 01:01.5 \\
\hline $55 \mathrm{~cm} \times 15 \mathrm{~cm}+$ Sugar -75 & 112.63 & 1.17 & 10.06 & 14.23 & 89.01 & 01:02.1 \\
\hline $45 \mathrm{~cm} \times 15 \mathrm{~cm}+$ Sweet Glory & 106.9 & 1.04 & 8.76 & 12.17 & 68.02 & 01:01.4 \\
\hline $\begin{array}{l}45 \mathrm{~cm} \times 15 \mathrm{~cm}+\mathrm{F}_{1}-\text { Hybrid } \\
\text { Indam-Suruchi }\end{array}$ & 106.23 & 1.03 & 8.69 & 12.1 & 67.21 & 01:01.4 \\
\hline $\begin{array}{l}50 \mathrm{~cm} \times 15 \mathrm{~cm}+\mathrm{F}_{1}-\text { Hybrid } \\
\text { Indam-Suruchi }\end{array}$ & 108 & 1.03 & 9.36 & 13.37 & 78.07 & 01:01.7 \\
\hline $\mathrm{CD}(\mathrm{P}=0.05)$ & 1.82 & 0.02 & 0.26 & 0.34 & - & - \\
\hline
\end{tabular}


investigation could be a reflection of the effect of plant geometry and variety. The yield was higher due to increase in the spacing and hence increase in the photosynthetic activity, which could lead to increase in photosynthesis, resulting in greater transfer of assimilates to the cob and causing increase in their yield. These results are conformity with. Sahoo and Panda (1999); Khan et al. (2002), Thavaprakaash et al. (2005); Chandenkar et al. (2005); this might due to more plant population at $60 \mathrm{~cm} \times$ $20 \mathrm{~cm}$ spacing which resulted in higher green cob and fodder yield Raja (2001).

\section{Straw yield}

Highest straw yield (2.85 t/ha) was recorded with $50 \times 15+$ Sugar -75 . The increase in cob and straw yield due to plant geometry is a clear reflection of increase in growth and yield attributes as the spacing helps in better dry matter partitioning, increase net photosynthesis.

\section{Economics}

Significantly higher net return (INR $90.56 \times 10^{3} /$ ha) was recorded in treatment $50 \mathrm{~cm} \times 15 \mathrm{~cm}+$ Sugar -75 because of minimum cost of cultivation, whereas highest benefit cost ratio (2.07) was recorded under treatment $55 \mathrm{~cm} \times 15 \mathrm{~cm}+$ Sugar -75 .

\section{CONCLUSION}

Treatment $50 \mathrm{~cm} \times 15 \mathrm{~cm}+$ Sugar -75 was found highest economic value in sweet corn under Uttar Pradesh climatic condition, whereas treatment 55 $\mathrm{cm} \times 15 \mathrm{~cm}+$ Sugar -75 found highest benefit cost ratio.

\section{REFERENCES}

1. Bouyoucus, G.J. 1927. The hydrometer as the new method for the mechanical analysis of soil. Soil Science, 23: 343-353.

2. Chandenkar, M.M. et al. 2005. Effect of different spacings on growth and yield of baby corn, Ann. Plant Physiol., 19(2): 172-174.
3. Dangariya, M.V., Dudhat, M.S., Bavalgave, V.G. and Thanki, J.D. 2017. Growth, yield and quality of Rabi sweet corn as influenced by different spacing and fertilizer levels. International Journal of Agricultural Science, 13(1): 38-42.

4. Kar, P.P., Barik, K.C., Mahapatra, P.K., Garnayak, L.M., Rath, B.S. and Bastia, D.K. 2006. Effect of planting geometry and nitrogen on yield, economics and nitrogen uptake of sweet corn (Zea mays). Indian Journal of Agronomy, 51(1): 43-45.

5. Khan, M.B., Asif, M., Aman, M. and Ahmad, T. 2002. Impact of intra-row spacing on growth and yield of some maize cultivars. Journal of Research (Science), Bahauddin Zakariya University, Multan, Pakistan, 13(2): 135-138.

6. Naik, A.A., Reddy, M.S., Babu, P.V. and Kavitha, P. 2019. Effect of plant density and nitrogen management on growth, yield and economics of sweet corn (Zea mays var. Saccharata). The Pharma Innovation Journal, 8(6): 839-842.

7. Raja, V. 2001. Effect of nitrogen and plant population on yield and quality of super sweet corn (Zea mays). Indian Journal of Agronomy, 46(2): 246-49.

8. Sahoo, S.C. and Mahapatra, P.K. 2007. Yield and economics of sweet corn (Zea mays) as affected by plant population and fertility levels. Indian Journal of Agronomy, 53(3): 239-42.

9. Sahoo, S.C. and Mahapatra, P.K. 2004. Response of sweet corn (Zea mays) to nitrogen levels and plant population. Indian Journal of Agricultural Sciences, 74(6): 337-338.

10. Sahoo, S.C. and Panda, M.M. 1999. Effect of nitrogen and plant population on yield of baby corn (Zea mays). Indian Journal of Agricultural Sciences, 69(2): 157-158.

11. Thakur, A.K., Thakur, D.S., Patel, R.K., Pradhan, A. and Kumar, P. 2015. Effect of different plant geometry and nitrogen levels, Inrelation to growth characters, yield and economics on sweet corn (Zea mays var. Saccharata) at Bastar Plateau Zone. The Bioscan, 10(3): 1223-1226.

12. Thakur, D.R. and Sharma, V. 2000. Effect of planting geometry on baby corn yield in hybrid and composite cultivars of maize. Journal of Agricultural Sciences, 70(4): 246-247.

13. Thavaprakaash, N., Velayudham, K. and Muthukumar, V.B. 2005. Effect of Crop Geometry, Intercropping Systems and Integrated Nutrient Management Practices on Productivity of Baby Corn (Zea mays L.) based Intercropping Systems. Research Journal of Agricultural and Biological Sciences, 1(4): 295-302. 
